\section{Links between phenology and ecophysiology in a European beech forest}

\author{
Josef Urban ${ }^{(1)}$, Emílie Bednářová(2), Roman Plichta ${ }^{(1)}$, Vladimír Gryc ${ }^{(3)}$, \\ Hanuš Vavrčík ${ }^{(3)}$, Jakub Hacura ${ }^{(3)}$, Marek Fajstavr ${ }^{(3)}$, Jirí Kučera ${ }^{(4)}$
}

Over the course of a year, tree physiological processes are not only directly affected by environmental conditions, but also by the tree's own phenological stages. At the same time, phenological stages should, to a certain degree, reflect tree physiology. However, we have rather poor knowledge of the details of the interplay between phenology and ecophysiology. The objective of this study was to develop a better understanding of the links between phenology and ecophysiology. We investigated the degree to which various physiological processes are synchronized both with each other and with phenology and what information related to phenology can be obtained from instrumental ecophysiological measurements. Phenological observations, along with measurements of transmittance of photosynthetically active radiation (PAR), stem volume changes, sap flow and xylogenesis were conducted in a 45-year old European beech (Fagus sylvatica) stand in the Czech Republic. Results indicated that ecophysiology was tightly related with the phenological stage of the tree. Early spring phenological stages were closely linked with the beginning of cambial activity and the onset of sap flow, i.e., the first leaves were produced simultaneously with the beginning of stem radial growth. The highest xylem growth rates occurred in June, simultaneously with the highest sap flow rates. Cambial activity ceased with the onset of summer leaf coloring at the end of July, at the same time as the permanent decrease in sap flow rate. The end of cell wall maturation was linked to the onset of autumn leaf coloring. We conclude that instrumental measurements of tree and stand ecophysiology provided additional information better specifying the onset of particular phenostages. In our case, twelve permanently located sensors used to measure PAR transmittance captured leaf area development with acceptable accuracy, thus limiting the need for frequent visits to the forest site in the spring and autumn. Moreover, data from dendrometers showed linkages to bud break and the onset of leaf coloring. Therefore, ecophysiological measurements increased the effectiveness and accuracy of phenological observations and provided additional information about tree development in particular external conditions.

Keywords: Phenology, Ecophysiology, Sap Flow, Xylogenesis, Photosynthetically Active Radiation, Dendrometers

\section{Introduction}

At scales ranging from organ to ecosystem, many processes, particularly those related to carbon cycling (productivity and growth) water (evapotranspiration and runoff), and nutrients (decomposition and mineralization), are directly mediated by phenology (Gu et al. 2003). Spring bud burst provides a particularly good example, as it involves various interactions between trees and the environment. The initiation of this phenological phase depends on early spring air and soil temperatures (Menzel 2000, Rossi et al. 2007, Lupi et al. 2012) as well as other environmental attributes such as photoperiod (Wareing 1953, Basler \& Körner 2012), precipitation and tree health. In turn, the seasonal cycle of leaf development determines many crucial aspects of forest canopy function, including photosynthetic uptake, radia- tion extinction, rainfall interception, and evapotranspiration (Bonan 1993, Saigusa et al. 2002). Foliage development, assessed at the stand level in terms of the leaf area index (LAI), typically increases rapidly in western European deciduous forests, from early May to mid-July, with the maximum around midJuly (Mussche et al. 2001). LAI affects the transmittance of photosynthetically active radiation (PAR) to the understory. Additionally, leaf development yields increases in transpiration (Střelcová et al. 2006).

Tree phenology is dependent on the plant's storage and consumption of carbohydrates (Michelot et al. 2012). These are stored in all organs (i.e., leaves, branches, roots, and stems) in different concentrations, which can vary during the growing season based on the relative rates of production and use (Scartazza et al. 2013). New photoassimilates trans-
(1) Department of Forest Botany, Dendrology and Geobiocenology, Faculty of Forestry and Wood Technology, Mendel University in Brno, Zemědělská 3, 61300 Brno (Czech Republic); (2) Institute of Forest Ecology, Faculty of Forestry and Wood Technology, Mendel University in Brno, Zemědělská 3, 61300 Brno (Czech Republic); (3) Department of Wood Science, Faculty of Forestry and Wood Technology, Mendel University in Brno, Zemědělská 3, 61300 Brno (Czech Republic); (4) EMS Brno, Turistická 5, 62100 Brno (Czech Republic)

\section{(a) Josef Urban (josef.urban@email.cz)}

Received: Apr 07, 2014 - Accepted: Sep 08, 2014

Citation: Urban J, Bednářová E, Plichta R, Gryc V, Vavrčík H, Hacura J, Fajstavr M, Kučera J, 2014. Links between phenology and ecophysiology in a European beech forest. iForest 8: 438-447 [online 2014-1215] URL: http://www.sisef.it/iforest/ contents/?id=ifor1307-007

Communicated by: Giorgio Matteucci

ported in phloem sap may be used for radial growth, with leaf phenology (i.e., budburst, leaf development and yellowing) thus influencing intra-annual wood formation (Čufar et al. 2008, Sass-Klaassen et al. 2011). The time lags between leaf and xylem growth phenologies vary among species, leading to differences in relative carbon allocation. In deciduous species, budburst generally occurs following radial growth for ring-porous species, whereas for diffuse-porous species, cambial division and consequent radial growth are initiated at almost the same time as budburst (Suzuki et al. 1996, Schmitt et al. 2000, Čufar et al. 2008). Nevertheless, even in diffuse-porous species, onset of cambial activity is sustained to a large degree by carbon accumulated in storage pools (Dietze et al. 2014).

Given sufficient soil water and based on atmospheric evaporative demand, maximal transpiration rates occur when trees have full foliage (Meier \& Leuschner 2008). However, numerous laboratory experiments on herbaceous plants and tree seedlings or saplings have shown that leaf coloring and leaf area reduction (i.e., events marking onset of particular phenological stages) are common responses to soil water shortage (Löf \& Welander 2000). Loss of leaves results in a decrease of the transpiring surface area, avoiding a severe reduction of cell water potential and turgor (Hinckley et al. 1981, Kozlowski \& Pallardy 1997). These interactions between leaf phenology and ecophysiology provide just one example of their mutual interplay, requiring multiple ap- 


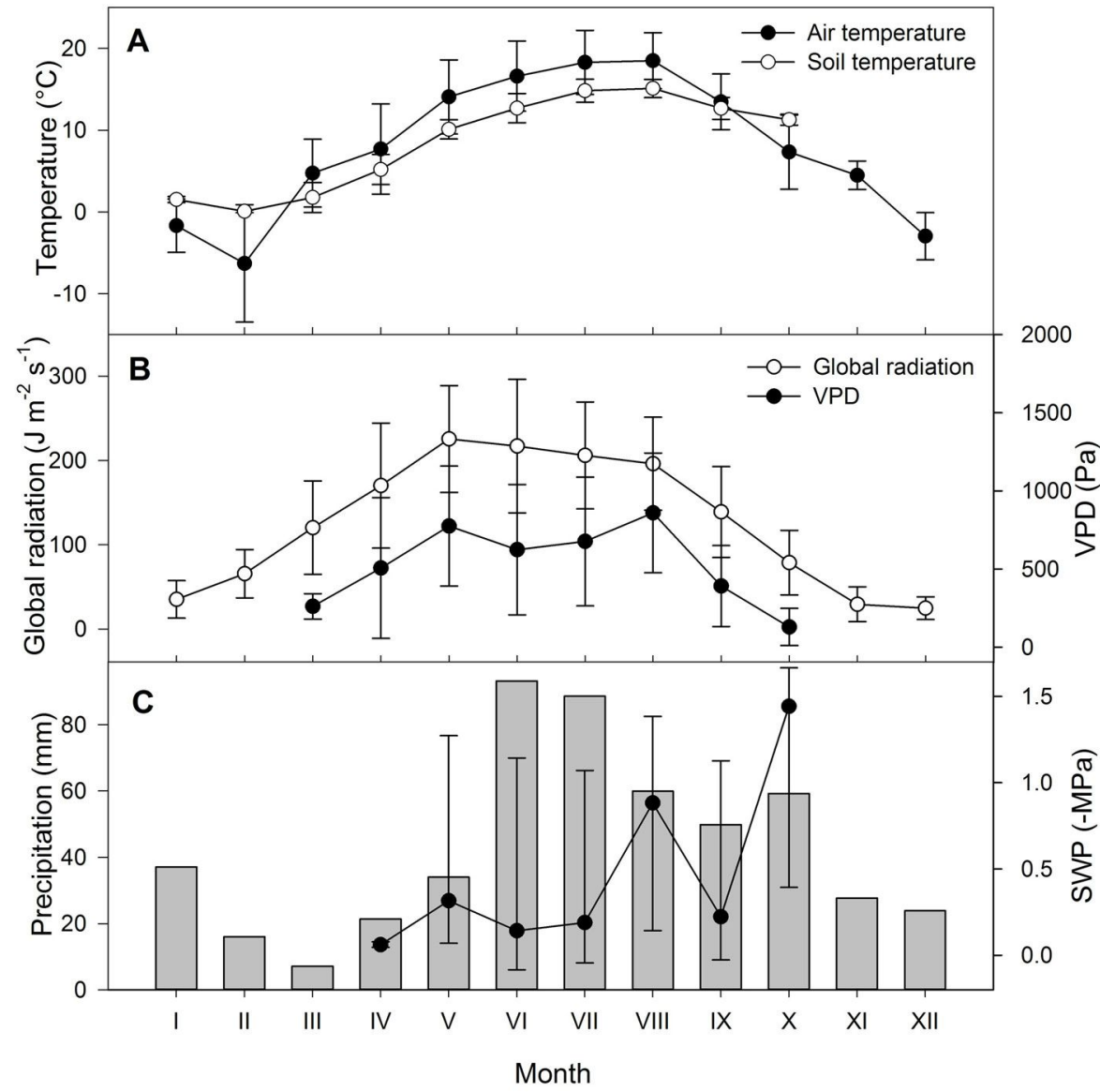

Fig. 1 - (A): Monthly means of daily mean air and soil temperatures ( \pm standard deviation). (B): Monthly means of daily mean global radiation and vapor pressure deficit $( \pm$ standard deviations). (C): Monthly precipitation sums (bars) and median values of the soil water potential (SWP, full circles \pm standard deviations of daily means from monthly means).

proaches to account for all of these processes (Michelot et al. 2012). However, although many authors have investigated the effects of particular phenomena, such as microclimate, genotype or tree health, on the phenological progress (Peuke et al. 2002, Bequet et al 2011), studies explicitly examining the interrelationships between environmental conditions, ecophysiology, and tree phenology are still scarce.

In the present study, we closely investigated the aforementioned relationships by assessing the correlation between phenology and multiple measurements of microclimate, soil characteristics, and tree development. We employed European beech (Fagus sylvatica) as a study species because it occurs in a broad range of soil-chemical, hydrological, and climatic conditions, including highly acidic to basic soils (Leuschner et al. 2006, Meier \& Leuschner 2008), low to high rainfall regimes, and low to high altitudinal zones (Prislan et al. 2011). Moreover, beech exhibits a number of physiological and morphological traits that characterize this species as relatively drought-sensitive $(\mathrm{Ba}-$ ckes \& Leuschner 2000, Granier et al. 2007), which should make responses to water availability relatively apparent.

At the study site, a beech stand in the Czech Republic, we recorded detailed phenological observations, canopy PAR transmittance, sap flow, stem increments, xylogenesis, and environmental conditions including air and soil temperature, precipitation, and soil water potential, during all the phenological phases in the 2012 growing season. The first aim of this study was to test the degree to which physiological processes are synchronized with each other and also related to phenological stages (especially in early spring), and particularly whether the beginning of cambial activity occurs simultaneously with budburst and sap flow onset. The second aim was to identify the extent to which continuous instrumental measurements of ecophysiological parameters be used instead or in support of regular phenological observations.

\section{Materials and methods}

\section{Meteorological measurements}

A meteorological station with a Minikin thermometer within a radiation shelter, global radiation sensor, PAR sensor, and precipitation gauge (EMS Brno, Czech Republic) was situated in a meadow $300 \mathrm{~m}$ apart from the experimental plot. Meteorological variables were measured every minute and stored as 10-min averages. At the experimental plot, soil water potential $(S W P)$ was measured at replicates at a depth of 20 $\mathrm{cm}$ using gypsum blocks (Delmhorst Inc., USA; data logger MicroLog SP, EMS Brno, Czech Republic) and stored every hour. Soil temperature was measured by a Pt 100 sensors at $20 \mathrm{~cm}$ depth, and stored every hour (data shown in Fig. 1). Reference evapotranspiration for the grass surface (ETo) was calculated from available meteorological data using the Food and Agriculture Organization of the United Nations (FAO) approach (Allen et al. 1998). Sums of the effective air temperatures were calculated as the sum of day means above the threshold value of $5{ }^{\circ} \mathrm{C}$ (Tab. 1).

\section{Research site and sample trees}

The experimental stand was a permanent plot located in forest stand 512D2 of the Czech Republic (49 26' 29.946" N, $16^{\circ} 42^{\prime}$ $06.237^{\prime \prime} \mathrm{E}$, altitude $600 \mathrm{~m}$ a.s.1.). The longterm mean air temperature and annual precipitation for the period 1960-1990 were 6.6 ${ }^{\circ} \mathrm{C}$ and $683 \mathrm{~mm}$, respectively. Annual precipitation in the study year (2012) was 518 $\mathrm{mm}$, and the mean air temperature was 7.9 ${ }^{\circ} \mathrm{C}$. The study site was classified according to the Czech forest type classification (Viewegh et al. 2003) as type 5S1 - Abieto-Fagetum mesotrophicum, while the soil was classified as cambisol oligotrophic. The stand was 45 years old, even-aged and composed entirely of European beech. The total stem basal area, as calculated from the diameter at breast height $(D B H)$ of stems, was $38 \mathrm{~m}^{2}$ $\mathrm{ha}^{-1}$. Ten sample trees were selected for the phenological observations. Six of them, with $D B H$ from 16 to $25 \mathrm{~cm}$, were chosen for detailed ecophysiological measurements of sap flow, xylem formation and stem diameter increments. Three of the selected trees were co-dominant (DBH 16.2, 18.9 and $20.0 \mathrm{~cm})$ while the remaining three were dominant (diameters 24.0, 24.7 and $25.3 \mathrm{~cm}$ ).

\section{Phenological observations}

Phenological observations were done using the methods of the Czech Hydro-Meteorological Institute (1987, Hájková et al. 2012). Phenological stages were monitored at ten sample beech trees (five dominant and five co-dominant trees) and subsequently scaledup from the tree to the stand level. Individual phenological stages were estimated visually every two days (every day whenever necessary during the spring), and once a week for the rest of the growing season. For each tree, the following phenological stages were 
recorded (Hájková et al. 2012): (i) “10\% bud break", $10 \%, 50 \%$, and $100 \%$ (denoted as " $10 \%, 50 \%$ and $100 \%$ " "first leaves", respectively) of leaves partially unfolded (midrib visible); (ii) full foliation (all leaves completely unfolded); (iii) summer coloring (in mid-summer, multiple stipules in various parts of the crown start turning yellow); (iv) $10 \%, 50 \%$, and $100 \%$ of leaves showing autumn coloring (denoted as " $10 \%, 50 \%$ and $100 \%$ " "leaves colored", respectively); and (v) leaf fall $10 \%, 50 \%$, and $100 \%$. The ordinal day number from the beginning of the calendar year (DOY) was recorded for the onset of each particular phenological stage for each sampled tree. The onset of each stage was determined at the stand level as the mean date of the sample trees $(n=10) \pm$ standard deviation. The DOY of onset of each stages was tested for differences between the dominant and co-dominant trees by repeated measure ANOVA $(\alpha=0.05)$. To place the observed phenology of the study year into a broader perspective, our data from 2012 were compared with long-term observations (1991-2012) of the same set of trees (Bednářová et al. 2010, unpublished data).

\section{Sap flow measurements}

Sap flow was measured on the stem of six of the sample trees, using the trunk heat balance technique (Čermák et al. 1973, 2004, Kučera et al. 1977) by means of the EMS51 heat balance system (EMS Brno, Czech Republic). The temperature difference between the heated and the reference part of the stem was fixed at $2 \mathrm{~K}$. Measuring points were installed on the north side of each stem (one per tree) and covered with reflective radiation shields. Measurements were taken from March $28^{\text {th }}$ until November $3^{\text {rd }}, 2012$. Data were obtained every minute and 10-minute averages were stored in the data logger. Upscaling of sap flow from individual trees to the forest stand was based on the regression between tree diameter and corresponding sap flow (Čermák et al. 2004). Before the upscaling, breast height diameters of all trees were measured and trees were divided into diameter classes with two centimeter resolution. Each of the classes was then considered as having the midpoint value of its diameter range (e.g., $14 \mathrm{~cm}$, for the $13-15 \mathrm{~cm}$ class) and the number of trees in each class was counted. The dependence of total sap flow on stem diameter was calculated for the entire period of field measurements (March $28^{\text {th }}$ to November $3^{\text {rd }}$ ) using a least-squares regression. The resulting equation was of the form (eqn. 1):

$$
Q_{D B H}=0.13 \cdot D B H-1.8
$$

$\left[\mathrm{kg}\right.$ tree $\left.^{-1} \mathrm{~h}^{-1}, \mathrm{R}^{2}=0.42, \mathrm{n}=6\right]$, where $Q_{\text {DBH }}$ is the sap flow (in $\mathrm{kg}$ tree ${ }^{-1} \mathrm{~h}^{-1}$ ) of a tree of

Tab. 1 - Dates of phenological stages. (DOY): days of the year \pm standard deviation (where applicable). Long-term averages cover the period 1991-2012 at the same site (Bednářová et al. 2010, unpublished data).

\begin{tabular}{llccc}
\hline $\begin{array}{l}\text { Phenological } \\
\text { stage }\end{array}$ & $\begin{array}{c}\text { DOY } \\
\text { in 2012 }\end{array}$ & $\begin{array}{c}\text { Long term } \\
\text { average DOY }\end{array}$ & $\begin{array}{c}\text { Sum of eff. } \\
\text { air T }>\mathbf{5}^{\circ} \mathbf{C}\end{array}$ & $\begin{array}{c}\text { Leaf area } \\
{[\%]}\end{array}$ \\
\hline Budbreak 10\% & $117 \pm 0.4$ & 104 & 98 & 0 \\
First leaves 10\% & $118 \pm 0.3$ & 113 & 109 & 5 \\
First leaves 50\% & $119 \pm 0.3$ & 116 & 123 & 15 \\
First leaves 64 $\pm 13 \%$ & 120 & - & 139 & 25 \\
First leaves $85 \pm 14 \%$ & 121 & - & 154 & 30 \\
First leaves 100\% & 122 & 121 & 170 & 33 \\
Full foliation 100\% & 131 & 132 & 256 & 100 \\
Bud formation & 161 & 164 & 509 & - \\
Shoot lignification & 164 & 168 & 534 & - \\
Summer colouring & 212 & 210 & 1181 & - \\
Leaf colouring 10\% & 257 & 266 & 1751 & - \\
Leaf fall 5\% & 275 & - & 1876 & - \\
Leaf fall 10\% & 287 & 285 & 1922 & - \\
Leaf fall 25\% & 289 & - & 1930 & - \\
Leaf colouring 50\% & 289 & - & 1930 & - \\
Leaf colouring 100\% & 294 & 297 & 1950 & - \\
Leaf fall 50\% & 309 & - & 1972 & - \\
Leaf fall 100\% & 315 & 311 & 1973 & - \\
\hline
\end{tabular}

given breast height diameter class, and $D B H$ is the diameter class of the tree (in $\mathrm{cm}$ ).

In order to obtain the sap flow of the entire stand $\left(Q_{\text {stand }}\right)$, tree sap flow values calculated per individual diameter classes were multiplied by the number of trees in the class per unit of ground area and then summed. The non-dimensional coefficient $S$ was then obtained by dividing the sap flow of all trees in the stand by the sap flow of the trees for which it was directly measured (eqn. 2):

$$
S=\frac{\sum Q_{\text {stand }}}{\sum Q_{\text {sample }}}
$$

The use of this coefficient allowed to estimate (in $\mathrm{kg} \mathrm{m}^{-2} \mathrm{~h}^{-1}$ ) the instantaneous values (i.e., diurnal courses) of sap flow $\left(Q_{\text {total }}\right)$ based on the actual transpiration of sample trees $\left(Q_{\text {sample }}\right)$, using the relationship (eqn. 3):

$$
Q_{\text {total }}=S \cdot Q_{\text {sample }}
$$

The resulting value was compared directly to the $E T \mathrm{o}$.

To assess both differences in flow between dominant and co-dominant trees and changes over the course of the growing season, we compared the average sap flow $\left(\mathrm{kg} \mathrm{h}^{-1} \mathrm{~cm}\right.$ of circumference $^{-1}$ ) of each tree to the overall mean sap flow value in the six trees subjected to sap flow measurement for each month over the period May-September. A two-way repeated measures ANOVA, with $\alpha$ $=0.05$ and tree status (dominant or co-dominant) and month as factors was used to test for significance.

\section{Stem diameter changes and phenology} of xylem formation

Stem diameter changes were measured at breast height of five of the sample trees using automatic band dendrometers (DR26, EMS Brno, Czech Republic). Data were stored in a data logger with a 10-min resolution. Measurements were taken from March $28^{\text {th }}$ until November $3^{\text {rd }}, 2012$.

Tissue samples for xylogenesis were collected using a Trephor tool (Rossi et al. 2006) at weekly intervals, from the end of March to the beginning of November 2011. The microcores (1.8 $\mathrm{mm}$ in diameter) were taken at breast height around the stem perimeter, such that they contained phloem, cambium and xylem of the developing tree ring. Immediately after sampling, the microcores were immersed in FAA (formalin-alcohol-acetic acid) where they were kept for a week, and then stored in 30\% ethanol. Microcores were dehydrated in an alcohol series $(70 \%, 70 \%, 90 \%, 95 \%, 100 \%$, and $100 \%$, then cleaned in xylene. The actual paraffin infiltration of microcores was carried out in a laboratory drying oven at $60{ }^{\circ} \mathrm{C}$ for 4 hours. Paraffin was poured by means of a dispenser, and the microcores were put into histological cases to be mounted in the microtome. A rotation microtome was then used to make $12-\mu \mathrm{m}$-thick cross-sections, that were dried in an oven at $60^{\circ} \mathrm{C}$ for 30 minutes. Further steps comprised removal of the paraffin with xylene, dehydration using ethanol and staining of the sections by safranin and astra blue. The sections were then mounted in Canada balsam. 

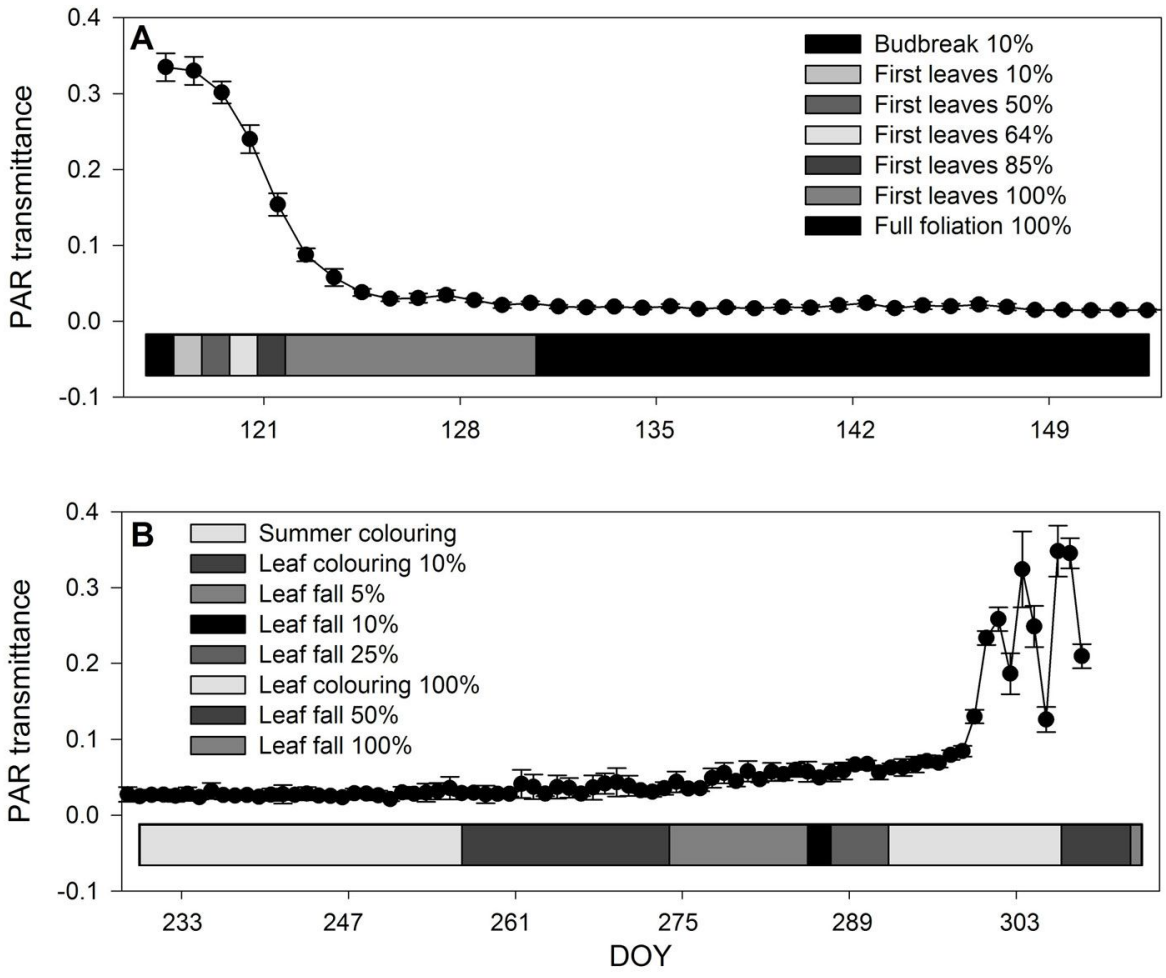

Fig. 2 - Spring (A) and autumn (B) phenological stages as related to light penetration through the canopy. Error bars indicates standard deviation $(n=12)$.

A microscope with an attached digital camera was used to photograph the microsections. The cross-sections were used to identify cambial cells (CC), postcambial cells (PC), wood cells in the secondary cell wall deposition phase (SW), and mature wood cells (MT). The CC zone was identified based on the thin cell wall and small radial dimension of the cell. In the PC phase, the cells still had thin cell walls, the lumina included protoplast, and the radial dimensions were at least twice those of CC. Use of po-

larized light allowed to distinguish cells in the SW phase from those in the PC phase, as during the SW phase cellulose microfibrils are deposited in the cell walls, and glisten in the polarized light. The lignification process was detected based on cell wall color change. Non-lignified cells were dyed blue with astra blue solution, whereas safranin solution dyed cells red due to its reaction with lignin. Cells of MT had red-stained cell walls and empty lumina without protoplasts. Measures of wood radial increments were taken using

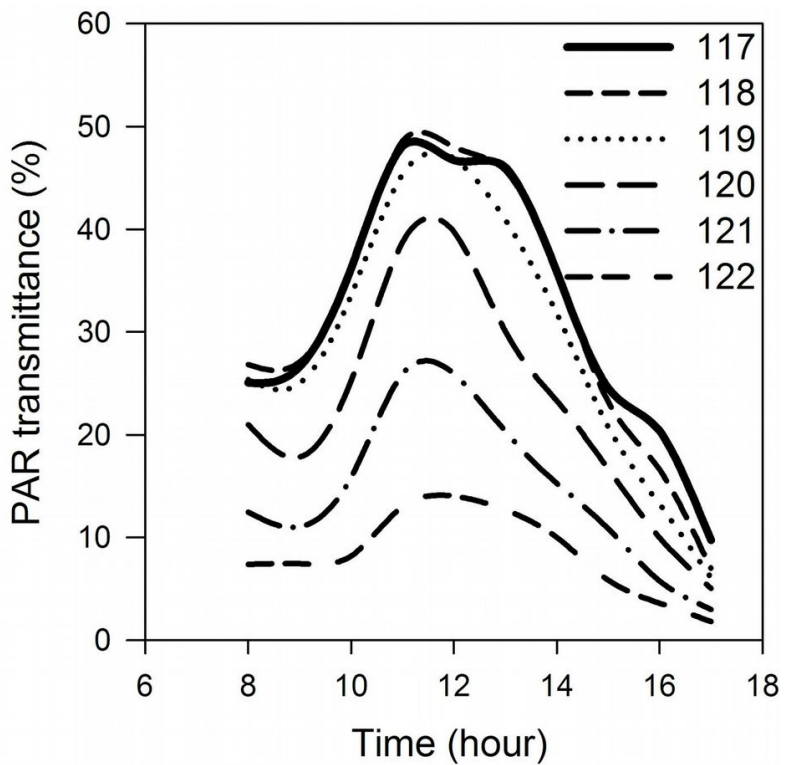

the free software package IMAGE $\mathbf{J}^{\circledR}$ (National Institutes of Health, USA).

\section{PAR transmittance of the canopy}

Overall, 12 PAR sensors (EMS12, EMS Brno, Czech Republic) were placed in a regular array (three rows, 4 meters apart) under the canopy of the experimental plot, 60 $\mathrm{cm}$ above the ground. Measurements were taken from March $28^{\text {th }}$ until November $3^{\text {rd }}$, 2012. Data were obtained each minute and stored in the data logger as 10-minute averages. Ambient PAR was obtained from the PAR sensor (EMS 12, EMS Brno, Czech Republic) at the meteorological station. PAR transmittance was calculated as the ratio of the mean understory PAR to ambient PAR. The relationship between PAR transmittance and sap flow per unit ground area $(E T, \mathrm{~mm}$ day $\left.^{-1}\right)$ standardized to evaporation demands of the atmosphere $\left(E T o, \mathrm{~mm}^{-1 a y}\right)$ was determined using the equation (eqn. 4 ):

$$
\frac{E T}{E T o}=a \cdot e^{-b \cdot t r a n s m i t t a n c e}
$$

where $a$ and $b$ are coefficients estimated by least-squares regression. Analysis was performed separately for the spring (DOY 117125) and autumn (DOY 245-305) periods using the least-squares regression method.

\section{Results}

\section{Phenology}

The beginning of bud break occurred on DOY 117 of 2012 (Tab. 1). Soil temperature increased that day to $6{ }^{\circ} \mathrm{C}$ and the sum of air temperatures above $5{ }^{\circ} \mathrm{C}$ accumulated to 98 ${ }^{\circ} \mathrm{C}$. The first leaves $50 \%$ stage occurred on DOY 119. First leaves $100 \%$ occurred on DOY 122. Full foliation was attained on DOY 131. No significant differences were found in spring phenology between dominant and co-dominant trees $(\mathrm{p}=1,0.35$ and 0.68 for bud break, first leaves $50 \%$ and first leaves $100 \%$, respectively). The first autumn phenological phase, summer coloring of stipules, occurred at the end of July, on DOY 212.

\section{PAR transmittance}

PAR transmittance ranged from $1.5 \%$ of ambient illumination, when the foliage was fully developed, to about $33 \%$, when shading was due only to bare branches (Fig. 2). Spring was characterized by rapid development of the foliage area. In five days, the transmittance dropped from 33\% (shading only by bare branches) to $9 \%$. In the next three days, transmittance decreased to $3 \%$. Further development of the leaf area was slower, and transmittance reached the stable value of $1.5 \%$ by the end of May (Fig. 2a). Details of diurnal curves of PAR transmittance in the first days of foliage development 
Fig. 4 - Changes in stem radius estimated by dendrometers on the stems of five different trees (lines show daily averages). Solid lines at the bottom of the graph indicate the onset of the stages of xylem formation in individual trees. (CA): beginning of cambial activity; (E): beginning of cell expansion; (W) onset of cell wall thickening; (M): first fully maturate cells; (ECA): end of cambial acti-

vity; (EE): end of cell expansion; (EM): fully formed ring. (DOY): ordinal day of year 2012. (DBH): breast height diameter.

are shown in Fig. 3. This graph shows not only a gradual decrease in PAR transmittance with the foliage growth, but more importantly that the time of the day when measurements are taken also matters, since transmittance changes significantly during the day from its minima in the morning and

Fig. 5 - Detail of tree ecophysiology in early spring phenological stages. (A): diurnal courses of ambient and understory photosynthetically active radiation (PAR). (B): changes in stem circumference in two dominant and three co-dominant trees. (C): diurnal courses of sap flow scaled per unit ground area (black line) and mean daytime values of PAR transmittance through the canopy (gray line and full circles: mean of twelve sensors \pm standard deviation).

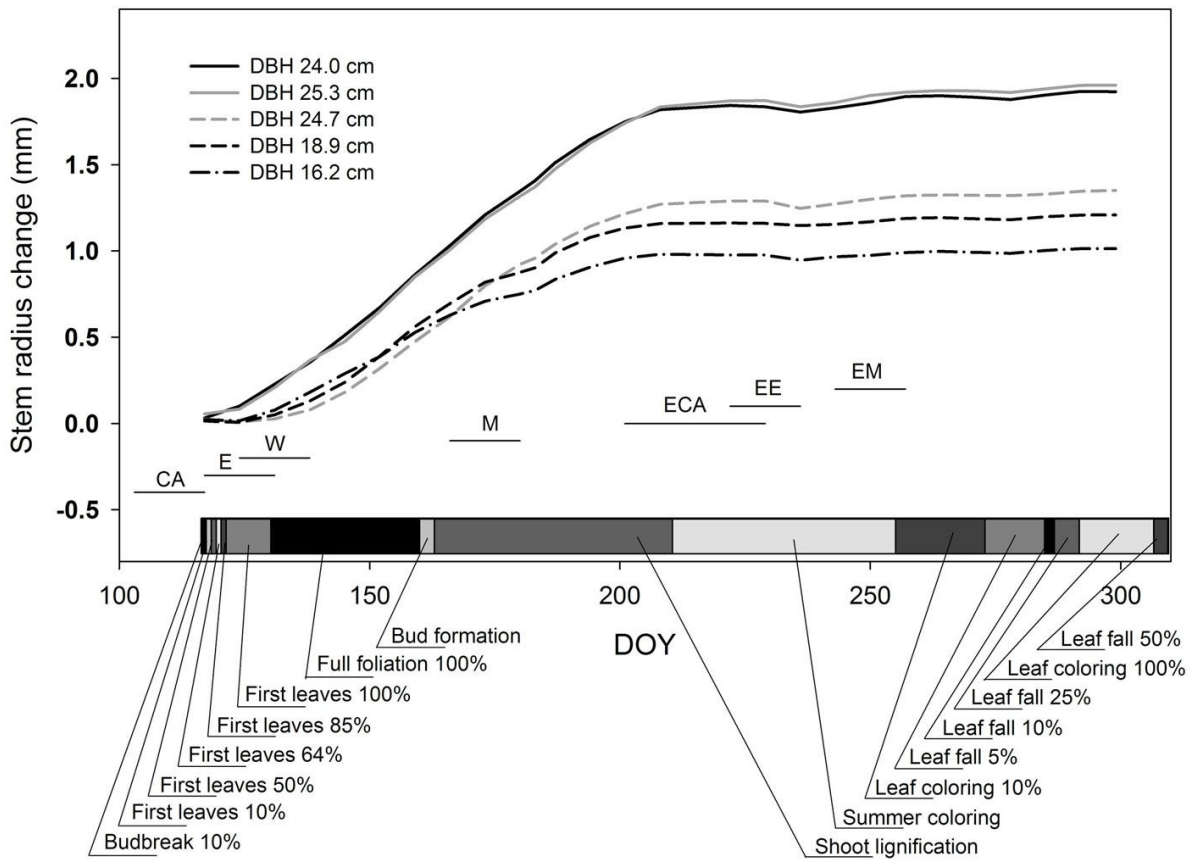

evening to its maximum at noon. Increase in transmittance over the course of autumn was not as rapid as its decrease in the spring. Also, the variability among days, as well as among individual measuring points, increased as a result of the lower angle of sun elevation and of greater cloudiness (Fig. 2b).
Stem growth increment and stem volume changes

Over the entire growing season (Fig. 4), the highest stem increments (up to $2 \mathrm{~mm}$ in radius per year) was observed for the largest dominant trees, due to their faster initiation of growth at the beginning of May, as com-

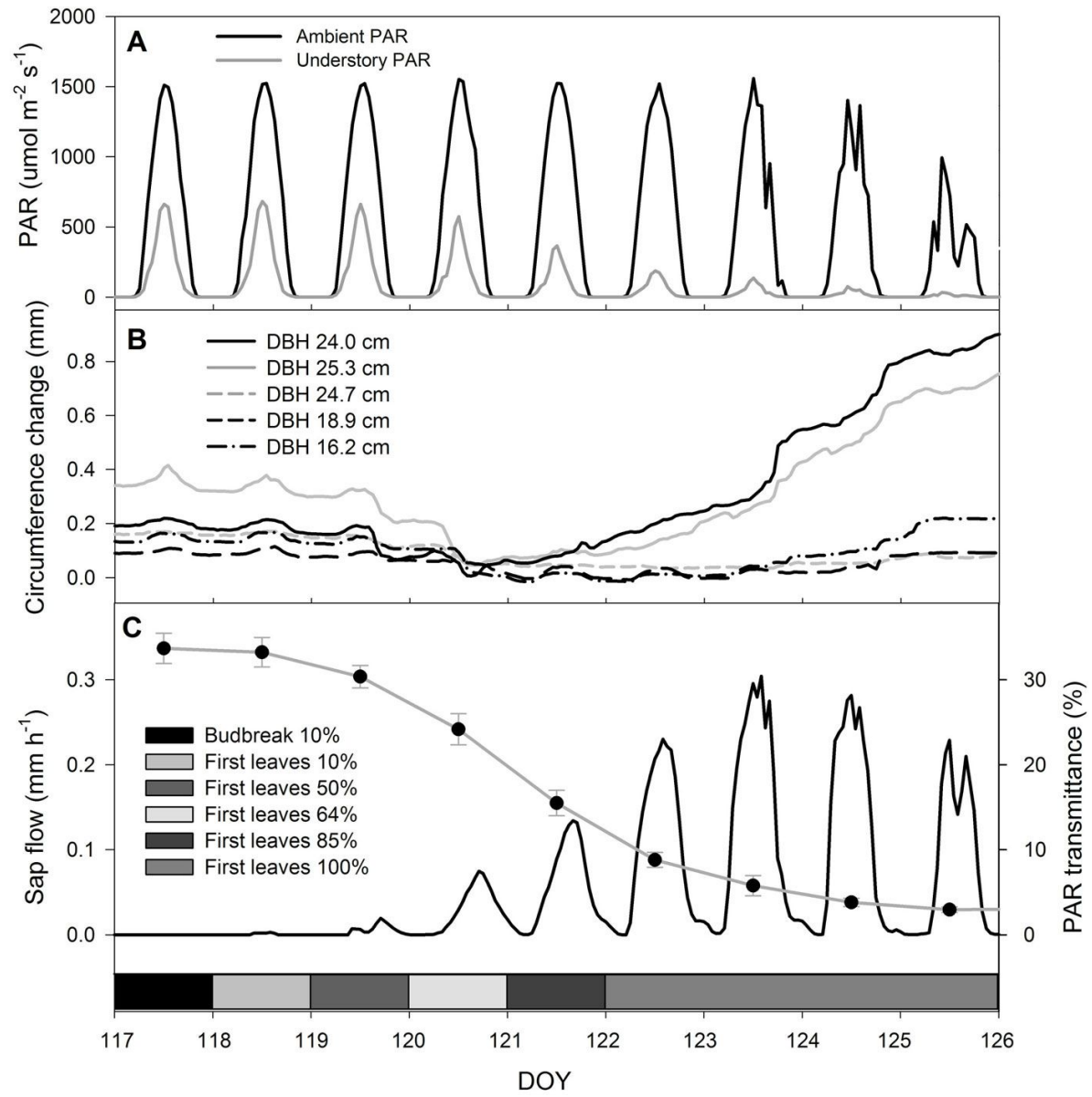




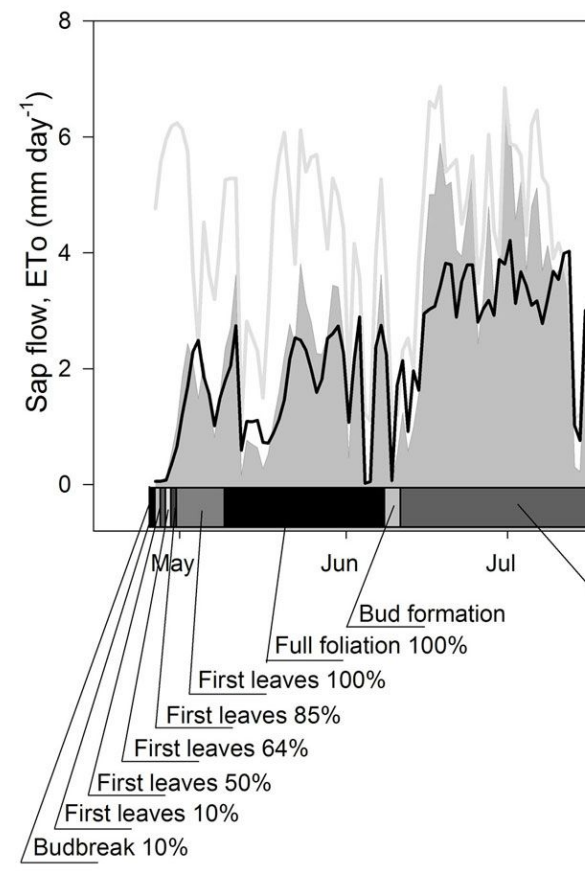

pared with co-dominant trees (Fig. 5b). First, almost negligible stem shrinkage was visible on the band dendrometers on DOY 118, followed by dramatic stem shrinkage on DOY 119. The smallest stem diameter was measured on DOY 120 in dominant trees and on DOY 121 in co-dominant and suppressed trees; these diameters increased starting at DOY 121 and 122, respectively (Fig. 5b).

Stem radial growth corresponded with the beginning of cell expansion (E) estimated from xylogenetic analyses (DOY 120); however, the cambium was active (CA) before the beginning of radial growth, i.e., the mean date of onset of active cambium was DOY 110 (Fig. 4). Onset of cell wall thickening (W) was observed almost two weeks after the onset of cell wall expansion (DOY 132). The first fully lignified cells were developed seven weeks after the onset of the expansion phase. Maximum growth rates were observed in June, when the leaf area was fully developed. Stem radial growth and cambial activity ceased with the onset of the summer coloring phenological phase. Cambium was active for 14 weeks. After growth had ceased (ECA) at the end of July, there were several shrinkage events in August and September, due to drought periods and intervening replenishment of depleted stem water reserves (Fig. 4). There were no statistically significant differences $(p>0.05)$ in onset or cessation of cambial activity between dominant and co-dominant trees.

\section{Sap flow}

Tree sap began to flow on DOY 119 and ceased with leaf fall by the end of October (Fig. 6). The highest rates of sap flow relative to ETo were reached in June and July.
Sap flow almost disappeared at the onset of the $10 \%$ leaf fall phenophase. The ratio of sap flow (per unit of stem circumference) to the mean sap flow of all measured trees was higher in dominant trees than in co-dominant trees, though not significantly $(\mathrm{p}=0.25)$. For each group of trees, these ratios did not show significant monthly variation over the period May to September $(p=0.78)$, with sap flow per unit of circumference in co-dominant trees ranging in individual months from 78 to $82 \%$ of the overall mean value and in dominant trees ranging from 117 to $121 \%$. Sap flow was exponentially dependent on spring leaf area development and autumn shedding, expressed as changes in PAR transmittance. The relationship between ET/ ETo (ratio of stand sap flow to reference evapotranspiration) and PAR transmittance was best described by the equations (eqn. 5):

$$
\frac{E T}{E T o}=1.08 \cdot e^{-11.4 \cdot \text { transmittance }}
$$

with $\mathrm{R}^{2}=0.99$ in spring (DOY 117-125), and (eqn. 6):

$$
\frac{E T}{E T o}=0.84 \cdot e^{-24.6 \cdot t \text { transmittance }}
$$

with $\mathrm{R}^{2}=0.39$ in autumn (DOY 245-305).

\section{Discussion}

\section{Phenology}

The beginning of bud break occurred 13 days later than the long-term (1991-2012) average (DOY $104 \pm 8$ SD). It had apparently been delayed by a cold spring, in which the mean air temperatures did not ex- ceed $5{ }^{\circ} \mathrm{C}$ until DOY 101. However, extremely warm weather between DOY 101 and 117 enabled accumulation of the sum of effective temperatures of $98{ }^{\circ} \mathrm{C}$, which was higher than the long-term average $53 \pm 30$ ${ }^{\circ} \mathrm{C}$, but still within the range $11-136{ }^{\circ} \mathrm{C}$ observed in the years 1991-2006 at the same site (Bednářová et al. 2010). The first few spring phenological stages (i.e., from bud break to first leaves $50 \%$ occurred faster than in previous years (1991-2012, Tab. 1), enabling the onsets of subsequent stages to be in accordance with their long-term averages. We did not find any significant difference in spring phenology between dominant and co-dominant trees $(\mathrm{p}=1 ; 0.35$ and 0.68 for bud break, first leaves $50 \%$ and first leaves $100 \%$, respectively). Overall, the timing of the autumn phenological phases was also in accordance with the long-term averages (Bednářová \& Merklová 2007, Bednárová et al. 2010). The exception was $10 \%$ autumn leaf coloring, which was five days later than the long-term average (Tab. 1). Even though the mean air temperature at the site was $1.3{ }^{\circ} \mathrm{C}$ higher than the long-term average for years 1960-1990, the temperature sum from the beginning of the year to $100 \%$ leaf fall $\left(1973{ }^{\circ} \mathrm{C}\right.$ in the year of study) was not significantly higher than the $1858 \pm$ $258{ }^{\circ} \mathrm{C}$ in the years $1991-2006$, confirming the warming trend at the site (Bednářová et al. 2010). The study year was also dryer by $165 \mathrm{~mm}$ of precipitation than the long-term average, resulting in several episodes of soil drought (Fig. 1c). Although soil drought probably had some effect on the onset of summer leaf coloring, as discussed later, the timing of phenological stages remain unaffected. This challenges the hypothesis of 
Backes \& Leuschner (2000) regarding the drought sensitivity of European beech, at least in terms of phenology.

\section{PAR transmittance}

Transmittance of PAR through beech canopy decreased during the initial stages of leaf development, as was generally predicted by the Lambert-Beer law (Vose et al. 1995, Hardy et al. 2004). During the day, PAR transmittance varied as the sun elevation angle changed (Fig. 3). This supports the contention of Hassika \& Berbigier (1998) and analyses of Kučera et al. (2002) that continuous PAR measurements or at least several measurements per day are necessary. Increase in transmittance in the autumn was not as rapid as its decrease in the spring (Fig. 2). Also variability among the days as well as among the individual measuring points grew up as a result of lower sun elevation angle and higher cloudiness. Since transmitted PAR is negatively correlated with leaf area utilization of PAR sensors increases objectivity of estimation of changes in leaf area.

\section{Stem growth increment and stem volume changes}

In the context of this study, we used stem circumference changes as a proxy for the assessment of two separate phenomena. The first is cambial activity and actual stem radial growth. The second is tree water potential. The fact that the first stem shrinkage was visible on the band dendrometers on DOY 118 confirmed that dendrometers are sensitive indicators of stem water potential (Cochard 2001, Deslauriers et al. 2007, Drew \& Downes 2009, Holtta et al. 2010, Ježík et al. 2014) in the transition period between sap flow from root pressure and from foliage-induced negative force. The dramatic stem shrinkage on DOY 119 without overnight refilling - due in part to night transpiration arising from rather high nighttime vapor pressure deficit and in part to probable natural shift from positive to negative xylem pressure (Kozlowski \& Pallardy 1997, Steppe et al. 2008) - indicated further decrease in the stem water potential as a result of transpiration.

Stem radial growth started with bud burst, according to previous studies for diffuse-porous species (Suzuki et al. 1996, Michelot et al. 2012). The date of the beginning of radial growth was the same when estimated from microcores as from dendrometers, unlike in conifers (Mäkinen et al. 2008). Stem enlargement from cell division and expansion was counteracted by stem shrinkage due to withdrawal of water from elastic tissues in this growth phase (Zweifel et al. 2001, Zweifel \& Hasler 2001, Čermák et al. 2007, Holtta et al. 2010). Therefore, it was impossible to identify the exact beginning of cambial activity and xylem cell expansion based on the dendrometer measurements. Moreover, assessment of cambial activity is strongly dependent on the method used. For example, Prislan et al. (2011) compared determinations of European beech cambial zone activity using observations made with light microscopy (LM), a standard tool used in xylogenesis studies, and transmission electron microscopy (TEM). Because the use of TEM for this purpose involves observation of different indicators, it enables the beginning of cambial activity to be identified a month earlier than by LM.

The timing and length of specific stages of xylem formation were in general accordance with European beech stands at sites with similar conditions in Europe. Prislan et al. (2011) showed that timing of cambial activity in European beech depends on the altitude. The length of cambial activity at our site (14 weeks at the altitude of $600 \mathrm{~m}$ a.s.1.) was similar to that observed by the above authors at their lower site in Slovenian mountains (16 weeks, $400 \mathrm{~m}$ a.s.l.). Cell division at our site started in the second half of April, which coincided with the development of the first leaves. This synchronization of the onset cambial cell activity with leaf unfolding is consistent with the beech study by Čufar et al. (2008). We found the most important month for tree ring formation was June, with maximum growth rates observed in the first half of this month, when the leaf area was fully developed. Similarly, Čufar et al. (2008) observed maximum weekly production approximately in the first week of June in Slovenia at $400 \mathrm{~m}$ a.s.l. However, Vavrčík et al. (2013) described maximum daily rates of wood production in European beech in the Czech Republic, at the same altitude as our study, in the second half of June 2010. This difference may be ascribed to the influence of specific weather and stand conditions on wood formation processes.

\section{Sap flow}

At the beginning of the growing season, sap flow was limited by leaf area and stomatal development and probably also by incomplete xylem growth-ring formation. Afterward, in June, when the leaves were expanded and soil water availability was not limited, it reached its maximum. However, at the end of July, sap flow levels decreased (simultaneous with the onset of summer leaf coloring) and did not recover even after rain events in August. Possible reasons for this include cavitation-based loss of xylem hydraulic conductivity in stem and leaves (Whitehead 1998, Leuschner et al. 2001, Ogasa et al. 2010), changes in stomatal conductance and loss of fine roots. Sap flow almost disappeared at the $10-25 \%$ leaf fall phenophase. Even though the remaining leaf area was high, the structural changes (i.e., formation of the suberin layer at the twig/ leaf interface) and less favorable weather lessened the sap flow to negligible levels.

\section{Linking of phenology and ecophysiology}

Spring is the period with the most rapid changes for trees, which have to activate metabolic processes, build (and repair) water-conducting pathways and develop photosynthetically active surfaces (Lemoine et al. 2002, Pallardy 2008). Only some aspects of such internal processes are directly visible on a tree. Phenology consists of a rather arbitrary and qualitative assessment of these external symptoms of seasonal tree development, whereas instrumental ecophysiological measurements provide quantitative information on particular aspects of tree life processes. Linking these two approaches may provide invaluable insight into the tree seasonal behavior.

Phenological and ecophysiological observations can complement each other, as they provide different information, with different resolution. According to phenological observations, bud burst occurred on DOY 117 . This process was not visible in the PAR measurements, and xylem water flow (if any) was beyond the resolution of the sap flow sensors. Very small amounts of stem shrinkage were visible in trees on the band dendrometers on DOY 118, which was the first indication given by instrumental methods that trees began to grow. The first statistically significant change in canopy transmittance occurred with the $50 \%$ first leaves stage on DOY 119. The same day, in the afternoon, the first measurable sap flow appeared (Fig. 5c). Observations of xylogenesis phases based on microcoring showed that the beginning of cell expansion occurred on DOY 120 (Fig. 4). The aforementioned facts suggest that for the precise indication of budburst, phenological observations are still irreplaceable. However, ecophysiological methods provide valuable information on later spring phenological stages, as well as on leaf development occurring within a few days after bud break.

The end of cambial activity occurred on DOY 208, shortly before the onset of summer coloring on DOY 212 (Tab. 1). It followed the short episode of soil drought at the end of July and was associated with a decrease in sap flow. Sap flow did not recover even after soil water had recharged at the beginning of August. Autumn phenological phases (including summer coloring) usually take much longer than spring phases. Given the considerable decreases in the values of external factors driving water vaporization (i.e., global radiation energy, air temperature and vapor pressure deficit) over the long time period comprising all the autumn phases, sap flow may be used for identification of the individual autumn phenological pha- 
ses only with difficulty. In our study, the loss of sap flow in the late autumn was better correlated with the degree of leaf yellowing than with the actual decrease in leaf area. The end of the vegetation season was also reflected in stem volume changes. After growth cessation, which occurred simultaneously with the summer leaf coloring, stem size changes followed those in water potential (i.e., shrinkage resulted from sap flow and swelling came from water refilling). During October, after termination of foliage activity, stems of all the studied trees continuously increased their diameters due to refilling of stem elastic tissues with water (Fig. 4).

The autumn phenological phases were better reflected in light transmittance. Recognition of the first phase (summer coloring) was, however, beyond the capabilities of the PAR sensors. Leaf coloring and defoliation were continuous, long-term processes. Therefore, no abrupt changes appeared in ligh transmittance. Nevertheless, even the 10\% leaf coloring resulted in an increased variability in the transmitted light. Later, 5\% and $10 \%$ leaf fall resulted in the statistically significant increase in the transmitted light $(p<0.05)$. Light transmittance at $50 \%$ leaf fall reached the same levels as in the spring, before leaf flush. Different sun elevation angles between the beginning and the end of the growing season enabled the same transmittance to be produced by different leaf areas. In the case of xylogenesis, only the end of maturation (DOY 247) could be correlated with first autumn phenological phase - leaf coloring $10 \%$ (DOY 257).

\section{Conclusions}

Phenology in deciduous tree species is tightly linked to ecophysiological processes. The beginning of cambial activity and the start of cell expansion occur with bud burst in European beech. The end of stem radial growth comes with the onset of summer leaf coloring. Measurements of PAR transmittance, stem volume changes, xylem formation and sap flow provided valuable additional information on the tree physiological states associated with the phenological phases and their transitions. Spring and autumn phenological phases differed in their dynamics (i.e., development of leaf area in spring was much faster than the loss of the leaves in autumn) as well as in absolute values of transpiration (which was lower per unit of leaf area in the autumn, due to lower evapotranspirative demands of the atmosphere) and stem volume changes.

Of the methods employed (sap flow, dendrometers, microcoring, light transmittance), PAR and dendrometer measurements were the easiest to use and allowed the simplest data evaluation. Therefore, we recommend complementing phenological observations with those measurements where possible. Moreover, modern techniques that enable remote data transfer from forest sites provide valuable tools to increase effectiveness of studies of phenological stages (minimizing the number of visits to the forest). Ecophysiological measurements alone, however, cannot provide accurate information about the onset of all of the phenophases, with the exception of bud break.

\section{Acknowledgements}

This research was supported by projects IGA Mendel University in Brno 8/2012, COST LD 13017 under the framework of the COST FP1106 network STReESS, OPVK CZ.1.07/2.3.00/30.0017 and OPVK CZ.1. 07/2.3.00/20.0265 co-financed by the European Social Fund and the state budget of the Czech Republic. The authors wish to thank Jonathan Rosenthal for his invaluable, detailed work on the language editing of the manuscript.

\section{References}

Allen RG, Pereira LS, Raes D, Smith M (1998). Crop evapotranspiration - Guidelines for computing crop water requirements. FAO Irrigation and drainage paper 56, FAO, Rome, Italy, pp. 300 .

Backes K, Leuschner C (2000). Leaf water relations of competitive Fagus sylvatica and Quercus petraea trees during 4 years differing in soil drought. Canadian Journal of Forest Research 30 (3): 335-346. - doi: 10.1139/cjfr-30-3-335

Basler D, Körner C (2012). Photoperiod sensitivity of bud burst in 14 temperate forest tree species. Agricultural and Forest Meteorology 165: 73-81. - doi: 10.1016/j.agrformet.2012.06. 001

Bednářová E, Kučera J, Merklová L (2010). The onset and duration of vegetative phenological stages in European beech (Fagus sylvatica L.) under changing conditions of the environment. Acta Universitatis Agriculturae et Silviculturae Mendelianae Brunensis 58 (4): 23-30. - doi: 10.11118/actaun201058040023

Bednářová E, Merklová L (2007). Vyhodnocení fenologie mladého smrkového porostu v oblasti Drahanská vrchovina [Phenology of young Norway spruce forest stand]. In: "Klima lesa" (Rožnovský J, Litschmann T, Vyskot I eds). Sborník Ref. - Mezinárodní Konf, Ceská bioklimatologická společnost, Krtiny, Czech Republic, pp. 54-58.

Bequet R, Campioli M, Kint V, Vansteenkiste D, Muys B, Ceulemans R (2011). Leaf area index development in temperate oak and beech forests is driven by stand characteristics and weather conditions. Trees 25 (5): 935-946. - doi: 10.1007 /s00468-011-0568-4

Bonan GB (1993). Importance of leaf area index and forest type when estimating photosynthesis in boreal forests. Remote Sensing of Environment 43 (3): 303-314. - doi: 10.1016/0034-4257 (93)90072-6
Čermák J, Deml M, Penka M (1973). A new method of sap flow rate determination in trees. Biologia Plantarum 15 (3): 171-178. - doi: 10.1007/ BF02922390

Čermák J, Kučera J, Nadezhdina N (2004). Sap flow measurements with some thermodynamic methods, flow integration within trees and scaling up from sample trees to entire forest stands. Trees 18 (5): 529-546. - doi: 10.1007/s00468004-0339-6

Čermák J, Kucera J, Bauerle WL, Phillips N, Hinckley TM (2007). Tree water storage and its diurnal dynamics related to sap flow and changes in stem volume in old-growth Douglas-fir trees. Tree Physiology 27 (2): 181-198. - doi: 10.1093/ treephys/27.2.181

Cochard H (2001). A new validation of the Scholander pressure chamber technique based on stem diameter variations. Journal of Experimental Botany 52 (359): 1361-1365. - doi: 10.1093/ jexbot $/ 52.359 .1361$

Čufar K, Prislan P, de Luis M, Gričar J (2008). Tree-ring variation, wood formation and phenology of beech (Fagus sylvatica) from a representative site in Slovenia, SE Central Europe. Trees 22 (6): 749-758. - doi: 10.1007/s00468-008-023 5-6

Czech Hydrometeorological Institute (1987). Metodologická príručka č. 10: Návod pro činnost meteorologických stanic - Lesní rostliny. [Methodology No. 10: Instructions for meteorological stations - forest plants]. Publishing house of Czech Hydrometeorological Institute, Prague, Czech Republic, pp. 111.

Deslauriers A, Rossi S, Anfodillo T (2007). Dendrometer and intra-annual tree growth: what kind of information can be inferred? Dendrochronologia 25 (2): 113-124. - doi: 10.1016/j.dendro.20 07.05 .003

Dietze MC, Sala A, Carbone MS, Czimczik CI, Mantooth JA, Richardson AD, Vargas R (2014). Nonstructural carbon in woody plants. Annual Review of Plant Biology 65 (1): 667-687. - doi: 10.1146/annurev-arplant-050213-040054

Drew DM, Downes GM (2009). The use of precision dendrometers in research on daily stem size and wood property variation: a review. Dendrochronologia 27: 159-172. - doi: 10.1016/j.dendro.2009.06.008

Granier A, Reichstein M, Bréda N, Janssens I, Falge E, Ciais P, Grünwald $\mathrm{T}$, Aubinet $\mathrm{M}$, Berbigier P, Bernhofer C, Buchmann N, Facini O, Grassi G, Heinesch B, Ilvesniemi H, Keronen P, Knohl A, Köstner B, Lagergren F, Lindroth A, Longdoz B, Loustau D, Mateus J, Montagnani L, Nys C, Moors E, Papale D, Peiffer M, Pilegaard K, Pita G, Pumpanen J, Rambal S, Rebmann C, Rodrigues A, Seufert G, Tenhunen J, Vesala T, Wang Q (2007). Evidence for soil water control on carbon and water dynamics in European forests during the extremely dry year: 2003. Agricultural and Forest Meteorology 143 (1-2): 123-145. - doi: 10.1016/j.agrformet.2006.12.004 Gu L, Post WM, Baldocchi D, Andy Black T, Verma SB, Vesala T, Wofsy SC (2003). Phenology of vegetation photosynthesis. In: "Pheno- 
logy: An Integrative Environmental Science" (schwarz MD ed). Tasks for Vegetation Science 39, Springer, The Netherlands, pp. 467-485. doi: 10.1007/978-94-007-0632-3 29

Hájková L, Voženílek V, Tolasz R (2012). Atlas of the phenological conditions in Czechia ( $1^{\text {st }}$ edn). Publishing house of Czech Hydrometeorological Institute, Prague, Czech Republic, pp. 311.

Hardy J, Melloh R, Koenig G, Marks D, Winstral A, Pomeroy J, Link T (2004). Solar radiation transmission through conifer canopies. Agricultural and Forest Meteorology 126 (3-4): 257 270. - doi: 10.1016/j.agrformet.2004.06.012

Hassika P, Berbigier P (1998). Annual cycle of photosynthetically active radiation in maritime pine forest. Agricultural and Forest Meteorology 90 (3): 157-171. - doi: 10.1016/S0168-1923(98) 00054-9

Hinckley TM, Teskey RO, Duhme F, Richter H (1981). Temperate hardwood forests. In: "Water Deficits and Plant Growth. Vol VI: Woody Plant Communities" (Kozlowski TT ed). Academic Press, London, UK, pp. 153-208. [online] URL: http://books.google.com/books?id=dK7o3RGqvh OC

Holtta T, Makinen H, Nojd P, Makela A, Nikinmaa E (2010). A physiological model of softwood cambial growth. Tree Physiology 30 (10): 1235-1252. - doi: 10.1093/treephys/tpq068

Ježík M, Blaženec M, Letts MG, Ditmarová L, Sitková Z, Střelcová K (2014). Assessing seasonal drought stress response in Norway spruce (Picea abies (L.) Karst.) by monitoring stem circumference and sap flow. Ecohydrology (early view). - doi: 10.1002/eco.1536

Kozlowski TT, Pallardy S (1997). Physiology of woody plants. Academic Press, S. Diego, CA, USA, pp. 427.

Kučera J, Bednářová E, Kamlerová K (2002). Vertical profile of needle biomas and pnetration of radiation through the spruce stand. Ekologia 21: 107-121

Kučera J, CCEermák J, Penka M (1977). Improved thermal method of continual recording the transpiration flow rate dynamics. Biologia Plantarum 19 (6): 413-420. - doi: 10.1007/BF02922976

Lemoine D, Cochard H, Granier A (2002). Within crown variation in hydraulic architecture in beech (Fagus sylvatica L.): evidence for a stomatal control of xylem embolism. Annals of Forest Science 59 (1): 19-27. - doi: 10.1051/forest:2001002

Leuschner C, Backes K, Hertel D, Schipka F, Schmitt U, Terborg O, Runge M (2001). Drought responses at leaf, stem and fine root levels of competitive Fagus sylvatica L. and Quercus petraea (Matt.) Liebl. trees in dry and wet years. Forest Ecology and Management 149 (1-3): 33-46. - doi: 10.1016/S0378-1127(00)00 543-0

Leuschner C, Meier IC, Hertel D (2006). On the niche breadth of Fagus sylvatica: soil nutrient status in 50 central European beech stands on a broad range of bedrock types. Annals of Forest Science 63 (4): 355-368. - doi: 10.1051/forest:20
06016

Löf M, Welander N (2000). Carry-over effects on growth and transpiration in Fagus sylvatica seedlings after drought at various stages of development. Canadian Journal of Forest Research 30 (3): 468-475. - doi: 10.1139/cjfr-30-3-468

Lupi C, Morin H, Deslauriers A, Rossi S (2012). Xylogenesis in black spruce: does soil temperature matter? Tree Physiology 32 (1): 74-82. - doi: 10.1093/treephys/tpr132

Mäkinen H, Seo JW, Nöjd P, Schmitt U, Jalkanen R (2008). Seasonal dynamics of wood formation: a comparison between pinning, microcoring and dendrometer measurements. European Journal of Forest Research 127 (3): 235-245. - doi: 10.1007 /s10342-007-0199-x

Meier IC, Leuschner C (2008). Leaf size and leaf area index in Fagus sylvatica forests: competing effects of precipitation, temperature, and nitrogen availability. Ecosystems 11 (5): 655-669. doi: 10.1007/s10021-008-9135-2

Menzel A (2000). Trends in phenological phases in Europe between 1951 and 1996. International Journal of Biometeorology 44 (2): 76-81. - doi: 10.1007/s004840000054

Michelot A, Simard S, Rathgeber C, Dufrene E, Damesin C (2012). Comparing the intra-annual wood formation of three European species ( $\mathrm{Fa}$ gus sylvatica, Quercus petraea and Pinus sylvestris) as related to leaf phenology and non-structural carbohydrate dynamics. Tree Physiology 32 (8): 1033-1045. - doi: 10.1093/treephys/tps052

Mussche S, Samson R, Nachtergale L, De Schrijver A, Lemeur R, Lust N (2001). A comparison of optical and direct methods for monitoring the seasonal dynamics of leaf area index in deciduous forests. Silva Fennica 35 (4): 373-384. doi: 10.14214/sf.575

Ogasa M, Miki N, Yoshikawa K (2010). Changes of hydraulic conductivity during dehydration and rehydration in Quercus serrata Thunb. and Betula platyphylla var. japonica Hara: the effect of xylem structures. Tree Physiology 30 (5): 608617. - doi: 10.1093/treephys/tpq011

Pallardy S (2008). Physiology of woody plants ( $3^{\text {rd }}$ edn). Academic Press, London, UK, pp. 454.

Peuke AD, Schraml C, Hartung W, Rennenberg H (2002). Identification of drought-sensitive beech ecotypes by physiological parameters. New Phytologist 154 (2): 373-387. - doi: 10.1046/j.14698137.2002.00400.x

Prislan P, Schmitt U, Koch G, Gričar J, Ä ufar K (2011). Seasonal ultrastructural changes in the cambial zone of beech (Fagus sylvatica) grown at two different altitudes. IAWA Journal 32: 443459. [online] URL: http://eprints.gozdis.si/590/ Rossi S, Menardi R, Anfodillo T (2006). Trephor: a new tool for sampling microcores from tree stems. IAWA Journal 27 (1): 89-97. - doi: 10.11 63/22941932-90000139

Rossi S, Deslauriers A, Anfodillo T, Carraro V (2007). Evidence of threshold temperatures for xylogenesis in conifers at high altitudes. Oecologia 152 (1): 1-12. - doi: 10.1007/s00442-006-06 25-7

Saigusa N, Yamamoto S, Murayama S, Kondo H,
Nishimura N (2002). Gross primary production and net ecosystem exchange of a cool-temperate deciduous forest estimated by the eddy covariance method. Agricultural and Forest Meteorology 112 (3-4): 203-215. - doi: 10.1016/S01681923(02)00082-5

Sass-Klaassen U, Sabajo CR, den Ouden J (2011). Vessel formation in relation to leaf phenology in pedunculate oak and European ash. Dendrochronologia 29 (3): 171-175. - doi: 10.1016/j.dendro.2011.01.002

Scartazza A, Moscatello S, Matteucci G, Battistelli A, Brugnoli E (2013). Seasonal and interannual dynamics of growth, non-structural carbohydrates and $\mathrm{C}$ stable isotopes in a Mediterranean beech forest. Tree Physiology 33 (7): 730-742. - doi: 10.1093/treephys/tpt045

Schmitt U, Möller R, Eckstein D (2000). Seasonal wood formation dynamics of beech (Fagus sylvatica L.) and black locust (Robinia pseudoacacia L.) as determined by the "pinning"" technique. Angewandte Botanik 74:10-16. [online] URL: http://www.cabdirect.org/abstracts/20000 612977.html

Steppe K, De Pauw DJ, Lemeur R (2008). Validation of a dynamic stem diameter variation model and the resulting seasonal changes in calibrated parameter values. Ecological Modelling 218 (34): 247-259. - doi: 10.1016/j.ecolmodel.2008.07. 006

Střelcová K, Priwitzer T, Mindáš J (2006). Fenologické fázy a transpirácia buka lesnéhov horskom zmiešanom lese [Phenological stages and transpiration of European beech in the mountain mixed forest]. In: "Fenologická odezva proměnlivosti podnebí” (Rožnovský J, Litschmann T, Vyskot I eds). Publishing house of Czech Hydrometeorological Institute, Prague, Czech Republic, pp. 1-14. [in Slovak]

Suzuki H, Yoda K, Suzuki M (1996). Phenological comparison of the onset of vessel formation between ring-porous and diffuse-porous deciduous trees in a Japanese temperate forest. IAWA Journal 17 (4): 431-444. - doi: 10.1163/2294 1932-90000641

Vavrčík H, Gryc V, Menšík L, Baar J (2013). Xylem formation in Fagus sylvatica during one growing season. Dendrobiology 69: 69-75. [online] URL: http://yadda.icm.edu.pl/yadda/eleme nt/bwmeta1 .element.agro-a5e3c0d6-e2a3-4110-8 998-206eb041ab67

Viewegh J, Kusbach M, Mikeska M (2003). Czech forest ecosystem classification. Journal of Forest Science 49: 74-82. [online] URL: http://www.agriculturejournals.cz/publicFiles/55 710.pdf

Vose JM, Clinton BD, Sullivan NH, Bolstad PV (1995). Vertical leaf area distribution, light transmittance, and application of the Beer-Lambert Law in four mature hardwood stands in the southern Appalachians. Canadian Journal of Forest Research 25 (6): 1036-1043. - doi: 10.1139/ x95-113

Wareing PF (1953). Growth studies in woody species. V. Photoperiodism in dormant buds of $\mathrm{Fa}$ gus sylvatica L. Physiologia Plantarum 6 (4): 
692-706. - doi: 10.1111/j.1399-3054.1953.tb084 42.x

Whitehead D (1998). Regulation of stomatal conductance and transpiration in forest canopies. Tree Physiology 18 (8-9): 633-644. - doi: 10.10 93/treephys/18.8-9.633

Zweifel R, Hasler R (2001). Dynamics of water storage in mature subalpine Picea abies: temporal and spatial patterns of change in stem radius. Tree Physiology 21 (9): 561-569. - doi: 10.1093/ treephys/21.9.561

Zweifel R, Item H, Hasler R (2001). Link between diurnal stem radius changes and tree water relations. Tree Physiology 21 (12-13): 869-877. doi: $10.1093 /$ treephys/21.12-13.869 